\title{
PELATIHAN PENGOLAHAN TELUR ASIN ASAP SEBAGAI UPAYA MENINGKATKAN NILAI JUAL TELUR ITIK SEGAR DI DUSUN CIHATEUP
}

\section{PROCESSING TRAINING ON SMOKED SALTED EGGS AS AN EFFORT TO INCREASE THE DUCK EGGS PRICES IN CIHATEUP HAMLET}

\author{
Andri Kusmayadi ${ }^{1) *}$, Ristina Siti Sundari ${ }^{2)}$ \\ ${ }^{1)}$ Fakultas Pertanian, Universitas Perjuangan, Tasikmalaya \\ email: andrikusmayadi@unper.ac.id \\ ${ }^{2)}$ Fakultas Pertanian, Universitas Perjuangan, Tasikmalaya \\ email: ristinasiti@unper.ac.id
}

\begin{abstract}
ABSTRAK
Dusun Cihateup sebagai wilayah domestikasi itik Cihateup memiliki potensi sebagai penghasil telur itik yang cukup melimpah. Telur itik di wilayah ini memiliki nilai jual yang relatif murah. Untuk meningkatkan nilai jual telur itik telah dilakukan pengolahan lebih lanjut menjadi telur itik asin. Pengolahan telur menjadi telur asin memiliki nilai jual yang lebih meningkat meskipun tidak signifikan dan daya tahan yang cenderung singkat. Oleh karena itu perlu dilakukan proses pengasapan pada telur asin sehingga nilai jual telur meningkat dan daya tahan produk semakin bertahan lama. Selain dengan metode pengasapan, penambahan asap cair pada proses pemeraman dilaporkan dapat meningkatkan nilai sensoris dan daya tahan produk telur asin yang semakin lama. Program pengabdian bertujuan untuk menyelesaikan permasalahan yang dihadapi oleh warga dan anggota kelompok ternak yang ada di Dusun Cihateup yaitu rendahnya nilai jual telur itik dan daya tahan telur yang relative singkat. Tujuan khusus pengabdian masyarakat ini yaitu meningkatkan nilai jual telur dan menyediakan produk telur itik yang tahan lama melalui metode pengasapan. Kegiatan berlangsung dari Januari sampai Juni 2020 di Dusun Cihateup Desa Sukanagalih Kecamatan Rajapolah Kabupaten Tasikmalaya. Metode pelaksanaan kegiatan terdiri atas penyuluhan, pelatihan dan pendampingan pada warga, wanita tani dan anggota kelompok ternak "Kelompok Megar Bebek Cihateup". Hasil program ini yaitu meningkatnya nilai jual dan pendapatan dari penjualan telur asin asap dan terciptanya produk telur asin asap yang memiliki daya tahan yang lebih lama. Pengolahan telur itik yang semakin banyak diduga mampu meningkatkan keuntungan lebih banyak.
\end{abstract}

Kata kunci: Dusun Cihateup, Pengasapan, Telur asin asap, Telur itik

\section{ABSTRACT}

Cihateup Hamlet as an area of domestication of Cihateup ducks has potential as a producer of sufficiently abundant duck eggs. Duck eggs in this region have a relatively cheap sale value. To increase the selling value of duck eggs, further processing has been done into salted duck eggs. Processing eggs into salted eggs has a selling value that is increasing even though it is not significant and the durability tends to be short. Therefore, it is necessary to process the fumigation of salted eggs so that the selling value of eggs increases and the durability of the product lasts longer. In addition to the fogging method, the addition of liquid smoke to the curing process is reported to increase the sensory value and the durability of salted egg products for longer. The service program aims to solve the problems faced by residents and members of livestock groups in the Cihateup hamlet, namely the low selling value of duck eggs and relatively short egg resistance. The specific purpose of this community service is to increase the sale value of eggs and provide long-lasting duck egg products through the smoking method. The activity took place from January to June 2020 in Cihateup Hamlet, Sukanagalih Village, Rajapolah District, Tasikmalaya Regency. The method of carrying out activities consists of counseling, training and mentoring to residents, farm women and members of the livestock group "Kelompok Megar Bebek Cihateup". The results of this program are the increase in sales value and income from the sale of smoked salted eggs and the creation of smoked salted egg products that have longer durability. Processing more and more duck eggs is thought to be able to increase profits more.

Keywords: Cihateup hamlet, Fumigation, Smoked salted eggs, Duck eggs 


\section{PENDAHULUAN}

Dusun Cihateup memiliki sumberdaya ternak lokal yaitu itik Cihateup sebagai penghasil daging dan telur. Ketersediaan telur di daerah ini cukup melimpah mengingat masih banyaknya peternak yang memelihara itik untuk mencukupi kehidupannya sehari-hari. Populasi itik di daerah ini masih cenderung stabil karena masih terdapat beberapa sentra penetasan itik yang menghasilkan bibit itik dengan persentase penetasan telur mencapai $80 \%$. Telur yang tidak layak ditetaskan berpotensi dijadikan sebagai telur konsumsi untuk mencukupi kebutuhan pangan hewani masyarakat. Produksi telur di Dusun Cihateup sebagai sentra pengembangbiakan itik Cihateup cukup melimpah. Peternak itik biasanya menjual telur itik segar dengan harga jual yang sangat murah yaitu sebesar Rp 2.000,00. Selain dengan menjual telur segar, peternak dan warga di Dusun Cihateup sudah ada yang mengolah telur itik menjadi telur asin.

Pengolahan telur asin di Dusun Cihateup sangat sederhana dan memiliki nilai jual yang relative murah yaitu sebesar $\mathrm{Rp} 2.500,00$ per butirnya. Kondisi ini menunjukkan bahwa pengolahan telur menjadi telur asin belum menunjukkan adanya peningkatan nilai jual yang signifikan dari harga telur itik segar. Dengan penerapan teknologi pengolahan telur asin yang sederhana menyebabkan telur asin cepat busuk sehingga diperlukan metode pengolahan lain yang dapat memperpanjang umur simpan telur asin. Metode pengasapan merupakan salah satu cara yang mampu memperpanjang umur simpan telur asin dengan cara mengkombinasikan panas dan zat kimia yang berfungsi untuk menghambat tumbuhnya bakteri [1]. Kondisi ini disebabkan kadar air yang terkandung di dalam telur asin hasil pengasapan tersebut jauh lebih sedikit sehingga dapat memperpanjang umur simpan telur asin asap menjadi lebih tahan lama [2]. Metode pengolahan telur dengan metode pengasapan selain menjadi lebih tahan lama juga dapat memberikan rasa yang unik dan spesifik [3] sehingga disukai konsumen.

Berdasarkan hasil uji sensoris, penambahan asap cair sebanyak $0,5 \%$ pada proses pembuatan telur asin yang direndam selama 8 hari menghasilkan sifat organoleptik yang paling disukai panelis (sampai 3,55 - 3,95) dibandingkan dengan telur asin yang tidak ditambahkan dengan asap cair $(3,25-3,50)$ [2]. Pengolahan telur menjadi telur asin asap dapat dilaksanakan dengan pengasapan saat telur sudah diasinkan, dapat juga diberikan penambahan asap cair pada larutan garam selama proses pemeraman telur itik. Asap cair telah banyak digunakan untuk pengawetan dan meningkatkan citarasa pada daging dan ikan segar karena mempunyai kelebihan yaitu biaya lebih murah dan tidak mengandung zat kimia berbahaya seperti hidrikarbon polisiklis aromatis (PAHs) [4] apabila dibandingkan dengan pengasapan konvensional. Pengasapan konvensional dilaporkan dapat menghilangkan bau amis telur, menghasilkan warna kerabang yang menarik, serta aroma khas asap yang menggugah selera [5]. Kombinasi asap cair dan 
pengasapan secara konvensional diduga dapat menghasilkan produk yang lebih tahan lama dengan citarasa yang lebih baik. Program pengabdian bertujuan untuk meningkatkan nilai jual telur dan menyediakan produk telur itik yang tahan lama melalui metode pengasapan.

\section{METODE PELAKSANAAN KEGIATAN}

Program pengabdian kepada masyarakat dilaksanakan pada Januari sampai dengan Juni 2020. Kegiatan pengabdian berlokasi di rumah anggota "Kelompok Ternak Megar Bebek Cihateup" yang berada di Dusun Cihateup, Desa Sukanagalih, Kecamatan Rajapolah, Kabupaten Tasikmalaya. Peserta kegiatan berjumlah 15 Orang yang terdiri atas warga, wanita tani dan anggota "Kelompok Ternak Megar Bebek Cihateup".

\section{Bahan dan Alat}

Bahan dan alat yang digunakan pada program pengabdian ini yaitu telur itik yang didapatkan dari "Kelompok Ternak Megar Bebek Cihateup", garam, asap cair, air, rak pengasapan, pisau, toples, label, plastik dan timbangan digital.

\section{Metode Pengabdian}

Rangkaian program kegiatan pengabdian masyarakat ini terdiri atas penyuluhan, pelatihan dan pendampingan dengan rinciannya sebagaimana tersaji pada Tabel 1 .
Tabel 1. Metode dan Rencana Kegiatan

\begin{tabular}{|c|l|l|}
\hline No. & Nama Kegiatan & $\begin{array}{l}\text { Metode } \\
\text { Pelaksanaan }\end{array}$ \\
\hline 1. & $\begin{array}{l}\text { Survey lokasi dan } \\
\text { permasalahan }\end{array}$ & Pendampingan \\
\hline 2. & $\begin{array}{l}\text { Pengenalan } \\
\text { teknologi } \\
\text { pengasapan dan } \\
\text { asap cair }\end{array}$ & Penyuluhan \\
\hline 3. & $\begin{array}{l}\text { Praktik pengolahan } \\
\text { telur asin asap }\end{array}$ & $\begin{array}{l}\text { Pelatihan dan } \\
\text { pendampingan }\end{array}$ \\
\hline 4. & $\begin{array}{l}\text { Monitoring dan } \\
\text { evaluasi program } \\
\text { ke mitra }\end{array}$ & Pendampingan \\
\hline 5. & $\begin{array}{l}\text { Analisis studi } \\
\text { kelayakan usaha }\end{array}$ & $\begin{array}{l}\text { Penyuluhan dan } \\
\text { pendampingan }\end{array}$ \\
\hline 6. & $\begin{array}{l}\text { Pengemasan dan } \\
\text { pemasaran produk }\end{array}$ & Pendampingan \\
\hline
\end{tabular}

\section{HASIL DAN PEMBAHASAN}

Telur itik merupakan salah satu sumber bahan pangan yang berasal dari peternakan itik yang memiliki kandungan gizi lengkap, mudah dicerna dan mudah didapat oleh masyarakat. Karakteristik telur sebagaimana bahan pangan lainnya terutama bahan pangan hewani yaitu mudah rusak sehingga diperlukan proses pengawetan dengan cara pengasinan menjadi telur itik asin sehingga memperpanjang masa simpan, meningkatkan nilai ekonomis dan memperkaya rasa [6]. Menurut Harianto [7], prinsip pengawetan telur yaitu untuk mencegah masuknya bakteri pembusuk ke dalam telur dan mencegah keluarnya air dari dalam telur. Selain dengan metode pengasinan, pengawetan telur itik juga dapat dilakukan dengan metode pengasapan. Pengasapan merupakan salah satu cara untuk memperpanjang umur simpan telur asin dengan cara mengkombinasikan panas dan zat-zat kimia untuk menghambat tumbuhnya bakteri [1],[8]. Pada program pengabdian ini 
telah dilakukan kombinasi pengawetan telur melalui metode pengasinan dan pengasapan. Bahan yang digunakan dalam proses pengasinan telur disajikan pada Gambar 1.

Bahan yang digunakan sebagai media pengasinan telur itik yaitu tanah porang yang didapatkan di pinggir sungai sekitar lokasi pengabdian dan garam yang sudah dihaluskan dengan persentase 50:50 dan dilarutkan dalam 1 liter air bersih. Selain itu, media pengasinan ditambahkan dengan asap cair agar produk tahan lama. Asap cair dilaporkan telah lama digunakan sebagai pengganti proses pengasapan konvensional untuk pengawetan dan sumber citarasa pada daging dan ikan [2]. Menurut Soldera dan Borrtolomeazzi [9], asap cair adalah salah satu hasil dari pirolisis kayu atau tanaman pada suhu sekitar $400^{\circ} \mathrm{C}$.

Telur itik yang sudah diambil dari peternak itik Cihateup di Dusun Cihateup selanjutnya dikumpulkan untuk diolah menjadi telur asin. Pertama, telur itik dibersihkan dari kotoran yang menempel pada kerabang telur agar terbebas dari kontaminasi mikroba yang dapat mengganggu dan merusak telur bagian dalam. Beberapa kelompok partisipan mencuci telur itik menggunakan air bersih dan mengeringkannya kembali menggunakan lap bersih agar telur tidak basah. Selanjutnya, telur yang sudah dibersihkan disimpan di dalam toples tertutup. Masing-masing telur pada kelompok perlakuan disimpan di dalam toples yang sudah dilabeli untuk selanjutnya dicampurkan dengan media pemeraman yaitu tanah kopral yang sudah dicampur dengan larutan garam dan asap cair. Telur yang sudah dibalut dengan media pemeraman selanjutnya dilakukan proses pemeraman selama 14 hari yang disimpan pada suhu ruang agar telur dapat terasa asin dengan sempurna. Setelah diperam, telur dicuci sampai bersih dari balutan media pengasinan untuk selanjutnya dikukus menggunakan api sedang selama 2 jam sampai telur menjadi matang. Hasil penelitian Wulansih [10] menunjukkan bahwa telur asin yang dikukus menghasilkan karakteristik kenyal pada tekstur putih telurnya, masir pada kuning telurnya serta menghasilkan warna kuning kehitaman pada bagian kuning telurnya, mudah dikelupas, dan tidak lengket.

Setelah proses pengukusan selesai selanjutnya telur asin dilakukan pengasapan. Ahmad dkk [11] melaporkan bahwa proses pengasapan telur asin dapat dilakukan setelah telur asin sudah dikukus terlebih dahulu (pengasapan metode dingin) ataupun pengasapan sekaligus pemasakan (pengasapan metode panas). Telur yang sudah matang selanjutnya dilakukan pengasapan menggunakan tungku dengan tinggi sekitar 1 meter menggunakan bahan bakar serabut dan tempurung kelapa yang masih basah agar tidak mudah terbakar namun menghasilkan asap yang cukup banyak. Saat proses pengasapan perlu dilakukan pemutaran telur agar pengasapan telur homogen artinya pengasapan merata pada semua bagian telur. Setelah proses pengasapan berlangsung selama kurang lebih 1 jam, selanjutnya telur dapat didinginkan dan disimpan pada wadah yang terbuka agar mudah 
menguap. Telur yang sudah diasap selanjutnya dikemas menggunakan kemasan plastic yang berisi 4 butir telur sehingga tampak rapih dan tidak mudah mengalami retak dan rusak.

Proses pembuatan telur asin asap dari awal sampai akhir perlu disosialisasikan kembali dalam bentuk penyuluhan dan pelatihan yang dibekali dengan makalah prosedur pembuatannya agar partisipan mudah memahami dan mengaplikasikannya. Setelah dilakukan penyuluhan dan pelatihan, selanjutnya dilakukan monitoring dan evaluasi secara berkala agar program berlangsung dengan optimal dan menghasilkan luaran program yang produktif. Kegiatan monitoring dan evaluasi dilakukan melalui pendampingan dengan ketua kelompok ternak dan apparat setempat. Program pengabdian ini dilaksanakan secara berkala selama 6 bulan dengan materi yang berbeda-beda mulai proses pembuatan telur asin asap, pengemasan sampai pemasaran produk.

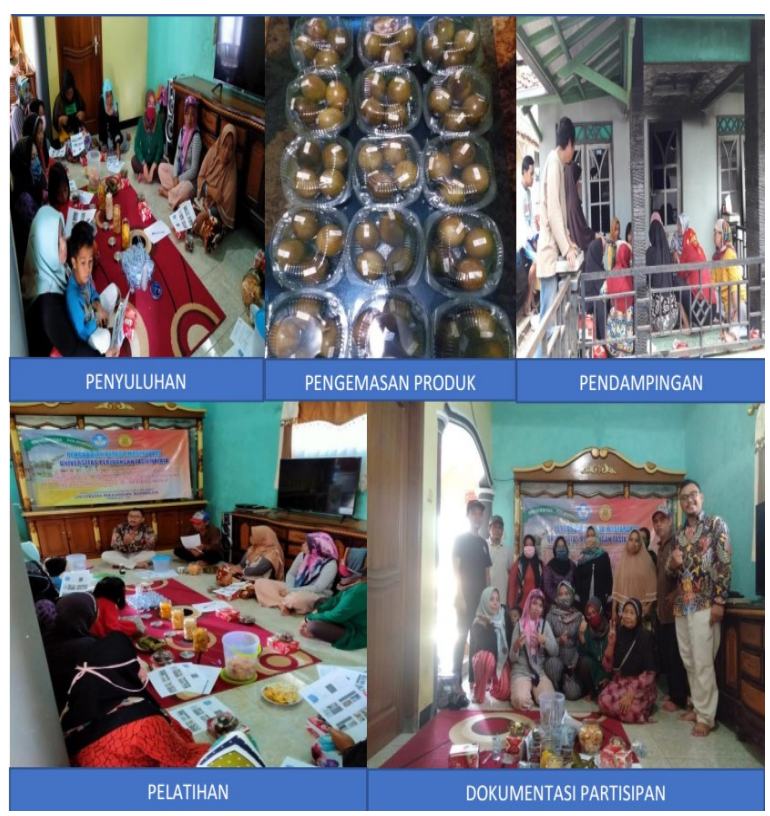

Gambar 1. Dokumentasi Kegiatan

Hasil dari program ini sudah dilakukan analisis pendapatan telur asin asap dalam sekali produksi yang disajikan pada Tabel 2.

Tabel 2. Komponen biaya pembuatan telur asin asap dalam sekali produksi

\begin{tabular}{llll}
\hline Komponen & Spesifikasi & Volume & Total (Rupiah) \\
\hline Pengeluaran & Telur Itik & $300 \mathrm{butir}$ & 600.000 \\
& Garam & $6 \mathrm{~kg}$ & 30.000 \\
& Tanah liat & $10 \mathrm{~kg}$ & 0 \\
& Asap cair & $100 \mathrm{ml}$ & 6.500 \\
& Bahan bakar & $1 \mathrm{karung}$ & 15.000 \\
& Kemasan & $75 \mathrm{pcs}$ & 45.000 \\
\cline { 2 - 4 } & Jumlah & & 696.000 \\
\hline Pemasukan & Telur asin asap & 75 bungkus & 1.125 .000 \\
\hline Keuntungan & & & 429.000 \\
\hline
\end{tabular}

Program pengabdian ini membutuhkan 300 butir telur yang dibeli dengan harga $\mathrm{Rp} 2.000,00$ per butir. Garam yang digunakan pada program pengabdian ini sebanyak $6 \mathrm{~kg}$ dengan harga garam per $\mathrm{kg}$ yaitu $\mathrm{Rp} 5.000,00$ sehingga totalnya sebesar Rp 30.000,00. Tanah liat yang digunakan pada program ini yaitu berasal dari pinggiran sungai di sekitar lokasi pengabdian sehingga tidak membutuhkan biaya. Asap cair diperoleh dari PT. Madaniah Yogyakarta dengan harga $\mathrm{Rp}$ 65.000,00 per liter dengan penggunaannya pada program ini sebesar 100 $\mathrm{ml}$ sehingga biaya yang dibutuhkan sebesar Rp 6.500,00. Plastik kemasan berjumlah 75 
kemasan dengan harga per kemasan sebesar Rp 600,00 sehingga totalnya Rp 45.000,00. Bahan bakar yang digunakan yaitu tempurung kelapa yang dibeli seharga $\mathrm{Rp} 15.000,00$ per karung dengan jumlah yang banyak sehingga cukup untuk mengukus dan mengasapi telur yang sudah diasinkan.

Telur hasil pengabdian selanjutnya dikemas dalam kemasan plastik yang berisi 4 butir per kemasannya. Harga telur tiap kemasan dijual dengan harga Rp 15.000,00 per bungkus dan berhasil menjual sebanyak 75 bungkus sehingga total penjualan sebanyak Rp 1.125.000,00. Berdasarkan analisis finansial, dapat disimpulkan bahwa keuntungan yang diperoleh dari proses pengolahan telur asin asap sebanyak 300 butir dapat menghasilkan keuntungan sebesar Rp 429.000,00 dalam sekali produksi. Jumlah keuntungan ini dapat ditingkatkan seiring dengan meningkatnya jumlah telur itik yang diolah.

\section{KESIMPULAN}

Program pengabdian berlangsung secara berkala selama 6 bulan dan menghasilkan luaran berupa dihasilkannya produk telur asin asap yang tahan lama serta meningkatnya nilai jual telur asin asap sehingga keuntungan meningkat. Keuntungan dari penjualan produk telur asin asap ini dapat ditingkatkan dengan penambahan bahan baku telur itik yang diolah dalam setiap produksinya.

\section{REFERENSI}

[1] Simajuntak, E., Wasito, S., Widayaka, K. 2013. Pengaruh lama pengasapan telur asin asap dengan menggunakan serabut kelapa terhadap kadar air dan jumlah bakteri telur asin asap. Jurnal Ilmu Peternakan, 1(1):195-200

[2] Nursiwi, A., Darmadji, P., Kanoni, S. 2013. Pengaruh penambahan asap cair terhadap sifat kimia dan sensoris telur asin rasa asap. Jurnal Teknologi Hasil Pertanian, 6(2):8289

[3] Widiastuti, S., Saloko, S. Murad, Rosmilawati. 2012. Optimasi proses pembuatan asap cair dari tempurung kelapa sebagai pengawet makanan dan prospek ekonomisnya. Agroteksos, 22(1):48-58

[4] Martinez, O, J. Salmerón, Guillén, M.D., and Casas, C. 2003. Texture profile analysis of meat products treated with commercial liquid smoke flavourings. Journal Food Control, 15 (6):457-461

[5] Fuadi, G. 2010. Pengaruh lama pengasapan dengan bahan bakar sabut kelapa (coco fiber) dan penyimpanan telur asin asap terhadap nilai gizi organoleptik. Skripsi. Universitas Andalas. Padang

[6] Rokana, E., Helilusiatiningsih, N., Sarbini, R.N. 2018. Diversifikasi produk telur asin melalui penambahan tanaman herbal dan proses penyangraian. Jurnal Dedikasi, 15:90-99

[7] Harianto A, 2016. Proses Pembuatan

Telur Asin. Kanisius. Yogyakarta

[8] Saukani, M., Irfan, I., Jaelani, A. 2019. Penerapan lemari asap terkontrol untuk produksi telur asin asap di industri rumah tangga Eldona, Banjarbaru. Jurnal Panrita Abdi, 3(2): 170-176

[9] Soldera, S.N., Borrtolomeazzi, R. 2008. Composition of phenolic compounds and antioxidant activity of commercial aqueous smoke flavoring. Journal of Agricultural and Food Chemistry, 56(8): 2727 - 2734

[10] Wulansih, S. 2008. Uji protein dan lemak pada telur asin hasil pengasinan dengan abu pelepah kelapa. Skripsi. Universitas Muhammadiyah Surakarta. Surakarta.

[11] Ahmad, N. 2016. Penuntun Praktikum Teknologi Hasil Ternak. Departemen Peternakan Fakultas Pertanian Universitas Sumatera Utara. Medan 